Dean of Liberal Arts at Howard University, died of cancer on August 27, 1997.

Born in Washington and raised in Meyersdale, Pennsylvania, Browne received his Bachelor's degree in political science from Howard University in 1938. After receiving a master's and doctorate in government from Harvard University, where he worked with Ralph Bunche, Browne served in the U.S. Army during World War II, attaining the rank of captain. In 1946, he returned to his undergraduate alma mater, where he would continue to teach courses in public administration and policy until the mid-1990s.

At Howard, Dr. Browne was, at different times, chair of the Department of Political Science, Administrative Assistant to two university presidents, and as Dean of the College of Liberal Arts. As Dean from 1968 to 1971, Browne presided over the largest college at the university during its most turbulent period, often encouraging student demonstrations. As Dean, Browne was instrumental in developing one of the nation's first programs in AfricanAmerican Studies. His publications include The Control of the Public Budget; "The Elimination of Segregation Executive Orders and Federal Administration Policies"; "Racial Desegregation in the Public Service, With Particular Reference to the United States Government"; "Civil Defense in the States and Cities"; and three lectures in the CBS-TV Black Heritage Series: "Segregation in Public Education: Pre-1954"; "The Evolvement of the 1954 Decision"; and "Response and Implementation of the 1954 Decision."

In addition to his work with the university, Browne served as a staff person of or consultant to the Federal Civil Defense Administration, the Federal Emergency Preparedness Administration, the Foreign Operations Administration (now AID), the Commission on Intergovernmental Relations, and the Veterans Administration. He was also Director of the Civil Rights Documentation Project, a member of the Board of Directors of the Washington Branch of the NAACP, President of the Washington Urban League, President of the National
Capital Area Political Science Association, which honored him with its Pi Sigma Alpha Award, and a member of several governing and planning committees of the American Political Science Association, including the committee which established the Association's education program.

Those wishing to honor Dr.

Browne's memory may make contributions to the Vincent J. Browne Memorial Scholarship, Political Science Department, Howard University, 2400 6th Street, NW, Washington, DC 20059.

Adapted from The Washington Post

\section{Joseph Hamburger}

Joseph Hamburger, Pelatiah Perit Professor of Political and Social Science, died on August 21, 1997 in New Haven, Connecticut. Hamburger had just completed work on a book on John Stuart Mill's On Liberty, to be published by Princeton University Press.

Through his teaching, his publications, his chairmanship of many conferences and seminars attended by scholars from across the country and the world, Hamburger was a widely recognized intellectual figure. His sturdy advocacy of the fundamental principles of individual liberty and representative democracy made him stand out, and often alone, from the ideological and cultural trends of recent decades. Professor Hamburger's love for intense and extended intellectual debate over the great texts of political thought revealed his study at the University of Chicago's Committee on Social Thought, of which he was one of the first to be granted a doctorate. He was a member of the Yale faculty from 1957 until his retirement in 1992.

As always in recent years, Hamburger was to have taught in the history and politics section of the prestigious Directed Studies program in which Yale freshmen encounter the great political, historical, philosophical and literary works of the past. Professor Hamburger's sly wit and constant congeniality made a lasting impression on his students of all ages. With his passing Yale has lost a figure of unusual intellectual and personal elegance, and an exemplar of the best traditions of university life in America.

In the past few years, Hamburger had participated in or led conferences on figures ranging from Hayek, Gibbon, Polyani, Macaulay and E.P. Thompson. During this past summer in Bozeman, Montana, Hamburger co-chaired a six-week seminar on Tocqueville and Mill. At his death he was preparing to conduct a colloquium on "Toleration and Free Inquiry in the Thought of George Grote," to be held in November in Savannah, Georgia. That conference will now go forward to honor his life and work.

Joseph Hamburger has added immensely to our knowledge of 19th century English intellectual history and political theory. His early books on James and John Stuart Mill examined the role of the disciples of Jeremy Bentham in passing the Reform Bill of 1832 and their failed efforts to organize a new parliamentary party. His 1976 volume $M a$ caulay and the Whig Tradition virtually rescued Macaulay as a thinker of weight and substance from the condition of near oblivion to which he had been consigned by the thendominant opinion. More recently he has co-auihored, with his wife Lotte, an intellectual biography of the English legal positivist John Austin and his wife and intellectual collaborator Sarah, entitled Troubled Lives (1985). This volume led to another joint publication entitled Contemplating Adultery (1991), a study of the Victorian sexual imagination. His work was supported with grants from the Guggenheim Foundation, the Earhart Foundation at the University of Chicago, the Rockefeller Foundation, the National Foundation for the Humanities and the Smithsonian Foundation's Woodrow Wilson Center Fellowship.

In addition to his wife, he is survived by three children, Annette, Philip and Jeffrey; a daughter-in-law, Dietlinde; and two grandchildren.

Norma Thompson

Charles Hill

Steven Smith

Yale University 